\title{
Proximate and Minor Mineral Content in Some Selected Basil Leaves of Ocimum gratissimum L, in Libya
}

\author{
A. M. Mlitan, M. S. Sasi, and A. M. Alkherraz
}

\begin{abstract}
Leaves of Ocimum gratissinum collected from Three different Locations in Misurata region (Zaroge, Tamena and Daphnia) in Libya was analyzed for proximate and minor minerals constituents. The proximate analysis to samples(Zaroge, Tamena and Daphnia)showed the percentage of crude protein content, moisture, lipids, ash and carbohydrate of the leaves on dry weight basis as $(9.10,10.60,14.3,50.35$, $10.08 \%),(9.80,10.40,11.0,14.5,52.45 \%)$ and $(9.22,10.60$, $55.20,13.19,11.16 \%)$ respectively. The percentages of minor mineral elements content were (Iron from 0.98 to $4.35 \mathrm{mg} / 100 \mathrm{~g}$ ), (Zinc from 10.44 to $17.72 \mathrm{mg} / 100 \mathrm{~g}$ ), (Copper from 0.45 to 3.75 $\mathrm{mg} / 100 \mathrm{~g}$ ), (Lead from 0.061 to $0.12 \mathrm{mg} / 100 \mathrm{~g}$ ) and (Cadmium from 0.011 to $0.018 \mathrm{mg} / 100 \mathrm{~g}$ ). The results of the analysis of basic components and a high proportion of protein, carbohydrates and minor mineral elements gave the basil importance of food and indicates its potential as a source of drugs.
\end{abstract}

Index Terms-O. gratissinum, proximate compositions, mineral elements.

\section{INTRODUCTION}

Medicinal plants are plants which contain substances that could be used for therapeutic purposes or which are precursors for the synthesis of useful drugs [1]. Ocimum gratissimum L. (family Lamiaceae) is an aromatic perennial herb wildely grown in Libya. The medicinal value of these plant sliesin bioactive Phyto chemical constituents that produce definite physiological action on the human body [2]. Ocimum gratissimum belongs to the family Lamiaceae and found mostly in countries including: Libya, India, North and South America, Mexico and Brazil where it is popularly known as alfavaca-cravo, alfavacao, alfavaca [3]. It's traditionally used to relief pains and also used in the treatment of rheumatism, diarrhea, high fever, convulsions, diabetes, eczema, piles and as a repellant [4], [5].The decoction of the stem is inhaled for the treatment of catarrh and bronchitis [6] Ocimum gratissinum is a shrub, 1-2m tall; anthropogenic of village areas, not found in the wild. The plant is common in West Africa and generally wide spread in tropical Africa. The leaves are broadly to narrow orate, usually $5-13 \mathrm{~cm}$ long and $3-9 \mathrm{~cm}$ wide. The flowers are gamopetalous and zygomorphic

Manuscript received November 17, 2013; revised February 25, 2014. A. M. Mlitan is with the Department of Chemistry, College of Science, University of Misurata, Libya (e-mail: adel_mlitan@yahoo.com).

M. S. Sasi and A. M. Alkherraz are with Department of Chemistry, College of Education, University of Misurata, Libya (e-mail: msasi40@yahoo.com, abdo_7979355176@yahoo.com). and exist in whorled and panicled inflorescence. The fruits of nutlets are subglose, $1.5-2 \mathrm{~mm}$ diameter and slightly rugose. Ocimum gratissinum is popularly used in folk medicine for the treatment of upper respiratory tract infection, diarrhea, cough, fever, gonorrhea, worm infection, stomach aches, headaches, pile, pneumonia and surface wound. It is also implicated in blood coagulation, anti- inflammatory, cardiovascular and renal function properties have been observed [7]. Ocimum gratissinum is a herbaceous plant which belongs to the Labiatae family. The plant is indigenous to tropical areas especially Libya and it is also in West Africa. The leaves of Ocimum gratissinum are used to prepare soups and porridge for women after delivery among the Igbos of Africa and also in the management of the baby's cord after delivery. The plant is used as food spice and for the treatment of ailments such as; malaria, diabetes, respiratory and urinary tract infections, cough, fever, diarrhea, abdominal pains, pneumonia, conjunctivitis, oral wounds and tooth infection [8], [9]. In this study, therefore, the leaves from three region of Ocimum gratissinum collected from Libya was analyzed for proximate and minerals constituents with view if there are variations in these accessions and if there are, to determine the heritable and non heritable components and estimates of heritability and genetic advance expected.

\section{AIM OF STUDY}

This study was under-taken to know the constituent of the leaves and mineral analysis of basil leaves Ocimum basilicum L. Zaroge Z, Tamena $T$ and Daphnia $D$ through proximate and mineral analysis

\section{MATERIALS AND METHODS}

\section{A. Plant Materials}

The fresh plants were collected locally from three states (Zaroge, Tamena a n d Daphnia) in Misurata region - Libya and after the species identification was done ,leaves were allowed to dry in open air in the shade area for 30 days air dered of powdered technically. Identi fication and authentication were carried out in Technology Laboratory of food science. Place of collection leaves shown in Table I.

TABLE I: OCIMUM GRATISSINUM ACCESSIONS SHOWING PlACE OF COLLECTION

\begin{tabular}{|l|l|l|}
\hline Accession & State collected & Town \\
\hline $\mathrm{Z}$ & Zaroge & Misurata \\
\hline $\mathrm{T}$ & Tamena & Misurata \\
\hline $\mathrm{D}$ & Daphnia & Misurata \\
\hline
\end{tabular}




\section{B. Processing of Plant Materials}

The fresh leaves of the following plants $O$. gratissimum, were air dried at $28^{\circ} \mathrm{C}$ for 30 days. They were grounded into fine powder using an electric blender and stored in a cool dry container until use.

\section{Proximate Analysis}

The proximate analysis of the samples for moisture, ash and fat were done by the method of [10]. The nitrogen was determined by micro-Kjeldahl method as described by [11], the percentage Nitrogen was converted to crude protein by multiplying 6.25 . The carbohydrate content was obtained by the difference as the nitrogen free extract. All determinat jons were performed in triplicates.

\section{Mineral Analysis}

The minerals of the samples were analyzed using the solution obtained by dry aching the sample at $550^{\circ} \mathrm{C}$ and dissolving it in $\mathrm{HCl}(25 \mathrm{ml})$ and $5 \%$ Lanthanum chloride $(2 \mathrm{ml})$, boiling, filtering and making up to standard volume with deionized water. $\mathrm{Cu}, \mathrm{Cd}, \mathrm{Zn}, \mathrm{Fe}$, and $\mathrm{Pb}$, were determined with a Buck Atomic Absorption Spectrometer (Buck Scientific, Model 200A/200, Inc. East Norwalk, Connecticut, U.S.A) [11] and [12]. The detection limits had previo usly been determine using the methods of Techtron [12] as $\mathrm{Cu} 0.005, \mathrm{Zn} \mathrm{0.005,} \mathrm{Fe}$ $0.02, \mathrm{Cd} 0.005$ and $\mathrm{Pb} 0.005 \mathrm{mg} / 100 \mathrm{~g}$ (all for aqueous solutions).The optimum analytical range was 0.5 to 10 absorbance units with coefficient to fvariation of 0.05 to $0.40 \%$ phosphor vanado-molybdatemeth dusinga Spectronic 20 colorimeter (Galenkamp, London, UK) [11]. All chemicals were $\mathrm{BDH}$ analytical grade.

\section{RESULTS AND DISCUSSION}

The results of proximate analysis(in\%) of O. gratissinum, Z. $D$ and $T$. guineensis leaves are shown on Table II. The plants contained higher amount of carbohydrates content which were $50.35,52.45$ and 55.20 respectively.These results are similar to that reported for A. sativum (57.28) [13], but are higher than that of Senna obstusfolia (23.70) and Amaranthus incurvatus (39.05) [14]. It is however lower than the value reported for $P$. fistulosus (62.39) [13]. Carbohydrate constitutes a major class of naturally occurring organic compounds which are essential for the maintenance of life in plant and animals and also provide raw materials for many industries [15]. The plant is a good source of carbohydrate when consumed because it meets the Recommended Dietary Allowance (RDA) values [16].

TABLE II: PROXIMATE COMPOSITION AND PH OF THE LEAVES OF SOME OCIMUM GRATISSINUM FROM LIBYA

\begin{tabular}{|l|l|l|l|}
\multicolumn{5}{l}{ OCIMUM GRATISSINUM FROM LIBYA } \\
\hline Test & Z & $T$ & $D$ \\
\hline Protein & $9.10 \%$ & $9.80 \%$ & $9.22 \%$ \\
\hline Moisture & $10.60 \%$ & $10.40 \%$ & $10.60 \%$ \\
\hline Fat & $10.80 \%$ & $11.0 \%$ & $11.16 \%$ \\
\hline Ash & $14.30 \%$ & $14.50 \%$ & $13.19 \%$ \\
\hline Carbohydrate & $50.35 \%$ & $52.45 \%$ & $55.20 \%$ \\
\hline PH & 5.50 & 5.34 & 5.40 \\
\hline
\end{tabular}

Key $: Z=$ Zaroge $;=$ Tamena $; D=$ Daphnia
The crude protein content (\%) of $O$. gratissimum, $Z, T$ and $D$ were $9.10,9.80$ and 9.22 respectively. These are higher than the protein content (7.00) reported by [17], but however lower than those(29.78) reported by [18] and (23.74) [19]. The ash content (in \%) of $O$. gratissinum, $Z, T$ and $D$ leaves were $14.03,14.50$ and 13.19 which is lower than the values reported for the leaves (22.84) by [19] and (15.09) with [20]. They are however higher than that (4.84) reported by [13]. The moisture content (in \%) values for the leaves of $O$. gratissimum, $Z$ (10.60), $T$ (10.40) and $D$ (10.60) were relatively low, therefore it would hinder the growth of micro organisms and life span of stored samples would be high. This is good for the long preservation and will prevent early spoilage. The moisture content of the plant is low when compared to that of Xylopia aethiopia (16.04) [21] and Acalypha hispida (11.91) Iniaghe et al., (2009). The values of the crude fat (in \%) for the leaves of O.garanissimu, Z. T and $D$ were $10.80,11.00$ and 11.16 respectively which were moderate in amount when compared to those (4.80)which reported by [18] and (3.15) with [21]. The results of proximate analysis on these three kind showed that they could be good for health by providing most of the essential nutrients for normal body functions when consumed in appropriate combinations. The mineral composition in ( mg/100g) of $O$. grantissimum, $Z, T$ and $D$ leaves were shown in Table III.

TABLE III: MINERALS COMPOSITION (MG/100G) OF O. GRATISSIMUM FROM

\begin{tabular}{|l|l|l|l|}
\multicolumn{5}{|c|}{ LIBYA } \\
\hline Elements & $Z$ & $T$ & $D$ \\
\hline Zinc & 17.72 & 20.05 & 10.44 \\
\hline Iron & 4.35 & 2.15 & 0.983 \\
\hline Lead & 0.090 & 0.061 & 0.123 \\
\hline Cadmium & 0.018 & 0.011 & 0.013 \\
\hline Copper & 3.19 & 3.75 & 0.454 \\
\hline
\end{tabular}

Key : $Z=$ Zaroge; $T=$ Tamena; $D=$ Daphnia

The value of Zinc content of $O$. gratissimum, $Z, T$ and $D$ varied from 10.44 to $20.05 \mathrm{mg} / 100 \mathrm{~g}$. These are low when compared to the mineral analyzed for in Pilostigma thioningi(70.10) [22]. Zinc is involved in normal functioning of immune system [23] and is associated with protein metabolism. The leaves are a good source of zinc because it is far above 6.23 recommended by RDA [24]. Iron content of $O$. gratissimum, $Z, T$ and $D$ varied from 0.98 to 4.35 $\mathrm{mg} / 100 \mathrm{~g}$. These values compared favorably with the values reported for Ipomea batata 16.00 [20], but low when compared to the values of other green leafy vegetables as reported by [23]. Iron is an essential trace element for hemoglobin format on, normal functioning of central nervous system and in the oxidation of carbohydrates, protein and fats [25].This perhaps justifies the already locally established function of the plant in the regulation of hemoglobin level. The values of Lead in the leaves of $O$. gratissimum, $Z, T$ and $D$ varied from 0.06 to $0.12 \mathrm{mg} / 100 \mathrm{~g}$, which are lesser than the suggested concentration of $2-6 \mathrm{mg} / \mathrm{g}$ in the plant species [26]. This suggest that $O$. gratissimum does not contribute or rather cannot be used as a substitute for other blood forming leafy vegetables while $Z, T$ and $D$ are involved in the boosting of the immune system and are antioxidant micronutrient [27]. 
The values of Copper in the leaves of $O$. gratissimum, $Z, T$ and $D$ varied from 0.45 to $3.75 \mathrm{mg} / 100 \mathrm{~g}$. copper deficiency has been reported to cause cardiovascular disorders as well as anaemia, bone disorder and nervous systems. Lead and Copper are highly toxic even at low concentrations. It is known that the lead element of the unnecessary elements of the body, which may cause its presence in concentrations large health problems. Finlay the values of Cadmium in the leaves of $O$. gratissimum, $Z, T$ and $D$ varied was from 0.011 to $0.018 \mathrm{mg} / 100 \mathrm{~g}$. Cadmium is considered non-essential elements of the human being and existence, even in small amounts may cause some health problems such as kidney failure and heart disease [28]-[30]. And generally may be due to the high concentration of some elements of this topic in the sample to the site, which grew when this kind of trees and over the proximity of the various sources of pollution (a main road, factory)

\section{CONCLUSION}

Ocimum gratissinum is a good source of nutrients for the indigenous people. Plants have contributed immensely to the medical field. It has been the source of most drugs used for combating infections. The plants used in this study were found to contain the important constituent needed to combat various kinds of infection in human.

\section{ACKNOWLEDGEMENT}

We wish to acknowledge University of Misurata and Technology Laboratory of food science for allowing us carry out this study in their chemistry laboratory and facilitating the collection of good samples.

\section{RECOMMENDED}

Further investigations are ongoing in our laboratory to determine the exact photochemical (plants Contain from Glycosides, Flavonoides, Risens and Alkaloids) for the activity of this plant and examined for Antimicrobial activity toward the bacteria: gram positive bacteria like Bacillus subtilis, Bacillus cereus, Bacillus sterother mophilis and gram negative bacteria like Pseudomonas aeruginosa, Proteus mirabilus, Klebsiella pneumoniae, Escherichia coli, and Salmonella typhimurium.

\section{REFERENCES}

[1] E. A. Sofowora, Medicinal plant and trditiona medicine in Africa, John Wiley and sons Ltd., pp. 1-10, 2008.

[2] C. A. Akinmoladun, E. O. Ibukun, E. M. Obuotor, and E. O. Farombi, "Phytochemical constituent and antioxidant activity of extract from leaves Ocimum gratissimum," Science Research Essay, vol. 2, pp. 163-166, 2007.

[3] P. M. Brenan, Flora of Tropical East Africa, East Africa Literature Bureau, Nairobi, 1996.

[4] D. J. Chitwood, "Phytochemical based strategies for nematodes control," Annual Review of Phytopathology, vol. 40, pp. 221-249, 2003.

[5] F. B. Hotlets, T. Ueda-Nakamura, D. A. G. Cortez, J. A. Morgad o-Diaz, and C. V. Nakamura, "Effects of essential oil of Ocimum gratissimum on the trypanosomatid Herpetomonas samuelpessoa," Act Protozool, vol. 42, pp. 269-276, 2003.
[6] L. S. Gills, "Ethnomedicinal uses of plants in Nigeria," University of Benin Press, Benin City, Edostate, Nigeria, pp. 65-75, 1992.

[7] P. K. Warrier, V. P. Nambiar, C. Ramankutty, Indian Meddicinal plan ts, vol. 3, Chennai: orient Longman pvy. LTd, pp. 303, 1995.

[8] B. A. Iwalokun, G. O. Ghenle, T. A. Adewole, and K. A. Akinsinde, "Shigellocidial properties of the Nigerian medicinal plants: Осimu mgrats simum, Terminalia aicennaoides and Monmerdica balsamma," Journal of Health, Population and Nutrition, vol. 19, pp. 331-335, 2003.

[9] I. I. I jeh, O. U. Njoku, and E. C. Ekenze, "Medicinal evaluat ion of ex tra cts of Xylopia aethiopica and Ocimum gratissimum," Journal of Medicin al an d Aromatic Plant Sciences, vol. 26, pp. 41-49, 2004.

[10] OAC, Official Methods of Analysis, 15th Association of Official Analysis Chemist Washinton D.C., pp. 774-784, 2005

[11] J. Pearson, Determination of phytic acid and phosphorus content of biological materials, Cambridge University Press, London, 1976.

[12] V. Techtron, Basic Atomic Absorption spectroscopy, A modern introduction, Domican Press, Victoria, Australia, pp. 104-10, 1975.

[13] N. M. Hussain, R. Muse, S. Ahmad, J. Ramali, M. Mahmood, M. R. Sulaiman, M. Y. A. Shukor, M. F. A. Rahman, and K. N. K. Aziz, "Anti fungal activity of extracts and phenolic compounds from Barringtonia racemosa L. (Lecythidaceae)," African Journal of Biotechnology, vol. 8, pp. 2835-2842, 2009.

[14] U. Z. Faruq, A. Sanni, and L. G. Hassan, "Proximate composition of sickle pod. Senna obstusfolia leaves," Nigeria Journal of Basic Applied Science. vol. 11, pp. 157-158, 2002.

[15] P. O. Ebun-Oluwa and A. S. Alade, "Nutritional Potential of Berlandier Nettle spurge (Jatropha cathatica) seed," Pakistan Journal of Nutrition. vol. 6, pp. 345-348, 2007.

[16] F. N. D. (2002). Food and Nutrition Board, Institute of Medicines. National Academy of sciences. Dietary reference intake for energy, (Micro-nutrients). [Online]. Available: http://www.nap.edu

[17] E. U. Isong and U. U. Idan, "Comparatives studies on the nutritional and toxic composition of three varieties of Lieanthera Africana," Plants Food and Hum Nutrition, vol. 51, pp. 79-84, 1997.

[18] A. A. Akindahunsi and S. O. Salawu, "Phytochemical screening and nutrient-antinutrient composition of selected tropical green vegetables," African Journal Biotech, vol. 4, pp. 497-502, 2005.

[19] M. Pandey, A. B. Abidi, S. Singh, and R. P. I. Singh, "Nutritional evaluation of leafy vegetables paratha," Journal Human Ecology, vol. 19, pp. 155-156, 2006.

[20] S. Antia, E. J. Akpan, P. A. Okon, and I. U. Umoren, "Nutritive and antinutritive evaluation of sweetpotatoes (Ipomea batata) leaves," Pakistan Journal of Nutrition, vol. 5, pp. 166-168, 2006.

[21] O. A. Abolaji, A. N. Adebayo, and O. S. Odesanmi, "Nutritional qualities of three medicinal plants: Xylopia aethiopicca, Blighia sapida and parinari polyandra," Pakistan Journal of Nutrition, vol. 6, pp. 665-668, 2007.

[22] J. A. Elegbede, A. U. Eka, and O. U. Osagie, Legumes, Nutritional Quality of Plant Foods, Post harvest research Unit, University of Benin. pp. 53-83, 1998.

[23] N. D. G. Ibrahim, E. M. Abdurahman, and G. Ibrahim, "Elemental analysis of the leaves of Veronia amygdaleina and its biological evaluation rats," Nigeria Journal of Natural Products Med, vol. 5, pp. 13-16, 2001.

[24] G. M. Borgert and H. Calloway, Nutritional and physical fitness, W. B saunder and Co., Philadephia, USA, pp. 34-50, 1975.

[25] E. Adeleye and M. K. O. Otokiki, "Proximate composition and some nutritionally valuable minerals of two varieties of Capsicum апnи," Discovery Innovations, vol. 11, pp. 75-81, 1999.

[26] T. C. Broyer, C. N. Johnson, and R. Pull, "Some aspects of lead in plant nutrition," Plant Soil, vol 36, pp. 301-305, 1972.

[27] G. P. Talwar, L. M. Sriva stave, and K. O. Mudgil, Textbook of Biotechnology and Human biology, 2nd ed. Prentice, half of India Private LTD. pp. 100-105, 1989.

[28] G. W. Mielcarz, A. N Howard, N. R. Williams, G. D. Kinsman, Y. S. Mizushima, and Y. Yamori, "Copper and Zinc Status as a Risk Factor for Ischemic Heart Diseases," The Journal of Trace Elements in Experimental Medicine, vol. 10, issue 1, pp. 29-35,1997.

[29] S. S. Asaolu, K. O. Ipinmoroti, C. E. Adeyinwo, and O. Olaofe, "Sea sonal variation in heavy metals distribution sediments of Ondo state coastal region," Ghana Journal of Chemistry, vol. 3, pp. 11-16, 1997.

[30] E. D. Fagbohun, O. U. Lawal, and M. E. Ore 2 , "The proximate, miner al and phytochemical analysis of the leaves of Ocimum gratissimum 
L," International Journal of Applied Biology and Pharmaceutical Technology, vol. 3, pp. 15-22, 2012.

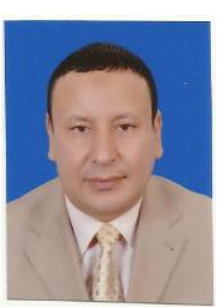

Adel Mohamed Mlitan was born on September 14, 1972 in Libyan, who received his B.Sc. in chemistry from Misurata University, Misurata, Libya in June 1994, got his M.Sc. degree in chemistry from Misurata University, Misurata, Libya in March 2001, and obtained his Ph.D. degree in biochemistry from
Sheffield University, Sheffield, United Kingdom (UK) May 2011. He was an assistant lecturer in biochemistry from June 2002 to 2011 and has been a lecturer in the Department of Chemistry, Misurata University, Misurata, Libya since October 2011. His speaks Arabic language (first language) and English language (second language), area of expertise includes air sensitive techniques including Schlenk line methods. UV, Luminescence and Use of IT such as Word, Chemdraw. Sigma plote.

Dr. Adel Mlitan is currently a lecturer in the Department of Chemistry, College of Science Misurata University, Libya, memberships in Libyan chemistry association. 